\title{
The effect of deemed dividend tax on dividend policy: evidence from Sri Lanka
}

\author{
MDDP Samarawickrema \& DLPM Rathnasingha \\ Faculty of Management and Finance, University of Colombo, Sri Lanka
}

\begin{abstract}
This study aims to find the effect of the Deemed Dividend Tax (DDT) on the dividend payout policy of companies in Sri Lanka. The sample of the study comprises of 100 companies listed on the Colombo Stock Exchange, excluding financial and power and energy sectors, for the period from 2003 to 2014. Further, the study uses the Tobit regression model to analyse the data. The findings of the study suggest that a large number of companies have initiated dividend distribution after the introduction of DDT in 2007 and that dividend payout of companies have increased significantly due to the introduction of DDT. On the other hand, relaxation of DDT threshold in 2011 has prompted companies to decrease the dividend payout, but to a lesser extent compared to the impact of introduction. The findings also discover that dividend income of a company has become a factor that affects dividend policy of a company significantly, after the introduction of DDT. Additionally, the findings show that profitability, stability of earnings, leverage and institutional and corporate ownership affect dividend policy of companies in Sri Lanka significantly. However, it is evident that liquidity position of companies is not considered in dividend policy decisions in Sri Lanka, as the companies are more concerned about reducing their tax liability by avoiding DDT. Moreover, the findings support signalling, catering and tax clientele hypotheses, but refute the tax effect hypothesis. In conclusion, the DDT has affected dividend payout policy of companies and has altered the factors that affect dividend policyin Sri Lanka.
\end{abstract}

Keywords -Dividend policy, deemed dividend tax, Colombo stock exchange 


\section{Introduction}

\subsection{Background of the study}

Tax liability of a company is basically two-fold where one component which company has to pay and bare while another component holds from payments to others and settle to inland revenue department. Among those dividend taxes of companies is special as above both components may be affected as per the situation and dividend tax and deemed dividend tax is considered in this study. Deemed dividend tax is an important factor for management on dividend payment decision. As a result, dividend policy is concerned with the financial policies determining the size and pattern of distributions of dividend to shareholders overtime. The dividend policy is important, as evidenced by the large amount of money involved and the attention that companies, security analysts, and investors give to dividends (Baker \& Weigand, 2015). A finance manager has to decide whether to distribute all or a proportion of earned profits in the form of dividends to the shareholders, or to be ploughed back into the business. Presumably, such decision should be taken, giving priority to the idea of maximizing shareholder wealth. Hence, "A company should endeavour to establish a dividend policy that will maximize shareholder wealth" (Van Horne \& Wachowicz, 2014).
Even though a large number of researchers have studied dividends in the past few decades, it is one of the enduring issues in finance that remains unresolved. Black (1976) describes dividends as a "puzzle" four decades before, and since then a vast number of studies have been conducted to solve the dividend puzzle. However, Al-Malkawi, Rafferty and Pillai (2010) conclude stating that," Although numerous studies have examined various issues of dividend policy, they have produced mixed and inconclusive results". This suggests that Black's (1976) statement about dividends is still valid.

\subsection{Tax system in Sri Lanka}

Dividend income of a person is liable for income tax in Sri Lanka as per section $3(\mathrm{e})$ in the Inland Revenue Act, similarly to most of the other countries. Dividends are taxed at the rate of $10 \%$ on dividend distributed. Companies have to deduct $10 \%$ from dividend distribution as withholding tax and remit such amounts to the Inland Revenue Department (Inland Revenue Department of Sri Lanka, 2014). Since the tax is deducted from gross dividend and only the net dividend after deducting the tax is distributed to shareholders, ultimate tax burden is on shareholders. However, this $10 \%$ withholding tax is considered as a final tax, and as a result shareholder do not have to pay taxes on dividend 
income at normal increasing tax rates from $4 \%$ to $24 \%$ as per individual tax rate schedule. Therefore, it is acknowledged that in Sri Lanka, dividends are taxed at a flat rate of $10 \%$ unlike other countries, where dividends are taxed at individual income tax rates.

In the year 2007, an innovative tax viz. 'Deemed Dividend Tax' (DDT) was introduced with the intention of persuading companies to increase their dividend distribution. DDT should not be misunderstood with dividend tax, as dividend tax is payable by shareholders when dividend is distributed, whereas DDT is payable by companies if a company does not distribute a specified amount as dividends. Thus, DDT is payable by companies who do not distribute at least $25 \%$ of distributable profit as dividends according to section 61 of the Inland Revenue Act. Further, DDT is taxable at $15 \%$ on excess of $1 / 3$ rd of distributable profit over dividend distributed (Inland Revenue Department of Sri Lanka, 2007). Since DDT is payable by companies, unlike dividend tax, the tax burden of DDT is on the companies. In 2011, the threshold that makes companies liable for DDT was relaxed to $10 \%$ from $25 \%$.

The impact of DDT on dividend policy is not known for certainty, as no research has been conducted relating to DDT and dividend policy, to the knowledge of the researcher. This may be mainly due to the fact that DDT is a new concept for taxation. This study bridges the above research gap through addressing the research problem: "What is the impact of Deemed Dividend Tax on dividend policy of Sri Lankan companies?" Therefore, the study is carried out with the objectives of finding the impact of introduction of DDT in 2007 on dividend payout policy of Sri Lankan companies, finding the impact of relaxation of DDT threshold in 2011 on dividend payout policy of Sri Lankan companies and finding the impact of dividend income received by a company on dividend payout policy of Sri Lankan companies. This knowledge is important for both finance managers of companies, policy makers in the country and to the public in general.

\section{Methodology}

\subsection{Variables}

Since the study aims to find the impact of DDT on dividend payout policy of companies, the dependent variable is considered as the dividend payout ratio of a company. Dividend payout ratio (DIVPAY) in table 1 is measured by dividing annual dividend per share by the annual earnings per share of companies. In order to capture the impact of the introduction of DDT in 2007, on dividend payout policy of companies, a dummy variable- POSTI, 
and to capture the effect of the relaxation of DDT threshold in 2011, on dividend payout policy of companies, dummy variable- POSTR, are used as key independent variables. Further, dividend tax is not payable when distributing company pay dividends, using dividend income received from other companies. In order to check if there is an association between dividend payout and dividend income, the dividend income (DIVINC) variable is incorporated into the model as an independent variable. DIVINC variable is measured by the proportion of dividend income from profit after tax of company, calculated by dividing annual dividend income by PAT.

In addition to the above variables, following factors possibly affecting dividend policy consistent with previous literature findings are also incorporated in the model as control variables. In the present study, profitability (ROE) variable is measured through annual return on equity of company. ROE is calculated by dividing profit after tax by total shareholders' equity in this study. Volatility of earnings of a company is another factor that affects dividend policy of companies as indicated by previous studies (Desalandes et al., 2015). Thus, volatility of earnings (VOLA) variable is calculated by the firm-level standard deviation of ROE over three years ( $t-2$ to $t$ ) following
Desalandes et al. (2015). This study uses debt to equity ratio (DEBT) to measure leverage of company and it is calculated by total liabilities divided by total equity of company at the end of the year. DeAngelo et al. (2006) has used the cash balance of companies to measure the liquidity position. Correspondingly, this study uses the cash balance at the yearend as a proportion of PAT to measure the liquidity position of company (LIQ). It is calculated by dividing cash balance as at the end of year by PAT of the company. Several researchers including Sri Lankan studies have found that institutional ownership also influences dividend policy of companies (AlNajjar, 2009; and Gunathilaka, 2014). In the current study, the corporate shareholders are also combined with institutional investors, when measuring INST variable. INST variable is measured by the percentage of institutional and corporate investors of the company, extracted from investor information section in annual reports.

Table 1. Operationalization of Variables Dependant variable

\begin{tabular}{ll}
\hline $\begin{array}{l}\text { Dependant } \\
\text { variable }\end{array}$ \\
\hline DIVPAY $\quad$ Dividend pay-out ration \\
\hline Independent \\
variables \\
\hline
\end{tabular}




\begin{tabular}{ll}
\hline POSTI & $\begin{array}{l}\text { impact of the introduction of } \\
\text { DDT in 2007, on dividend } \\
\text { payout policy of companies, a } \\
\text { dummy variable }\end{array}$ \\
\hline POSTR & $\begin{array}{l}\text { impact of the relaxation of DDT } \\
\text { threshold in 2011, on dividend } \\
\text { payout policy of companies, } \\
\end{array}$ \\
& dummy variable \\
\hline DIVINC & Dividend income \\
\hline ROE & Return on equity (profitability) \\
\hline VOLA & Volatility of earnings \\
\hline DEBT & Debt to equity ratio \\
\hline LIQ & Liquidity position \\
\hline INST & Institutional investors \\
\hline
\end{tabular}

\subsection{Sampling and data collection}

The population of the study is all companies listed in the Colombo Stock Exchange (CSE) of Sri Lanka. The study period contains 3 sub periods, namely; period prior to introduction of DDT in 2007 (PRE), period subsequent to introduction of DDT (POSTI) and period subsequent to relaxation of DDT threshold in 2011 (POSTR). The researcher has selected 2003 to 2014 (12 years) as the period of study in order to have similar duration sub periods (PRE: 2003-2006, POSTI: 2007-2010, POSTR: 2011-2014). The initial sample for the study is derived from the companies listed on the CSE throughout the period 2003 to 2014. Financial institutions (27 companies) were excluded from the sample because of the high leverage that is normal for the financial institutions, perhaps does not have the same meaning as for nonfinancial companies, where high leverage more likely indicates distress as noted by Fama and French (1992) in 'The Cross-Section of Expected Stock Returns'. In addition, there were no companies listed under the power and energy sector throughout the period of study. From the remaining sample, 100 companies were selected randomly using stratified sampling method, contributing to 1200 firm-year observations (annual data of 100 companies for 12 years). The population is stratified into $18 \mathrm{sub}$ divisions according to the business sector the companies are classified in the CSE. Equal weightage was given for each sector when selecting the final sample and data were collected from audited financial statements included in the annual reports of the selected sample companies.

\subsection{Research models}

1) Model 1: The main model of the research study functions to find the impact of DDT on dividend payout of companies in Sri Lanka. The model captures the effect of introduction of DDT in 2007 and relaxation of DDT threshold in 2011, on dividend payout. The model also incorporates the other factors, possibly affecting dividend policy of companies as evidenced by 
previous literature. Therefore, the model measures the determinants of dividend policy of companies in Sri Lanka during the period of study as a whole (20032014). Following the model used by Desalandes et al. (2015) in their study of effect of tax cut in Canada, the researcher has developed the below mentioned modified model to examine the impact of DDT on dividend payout.

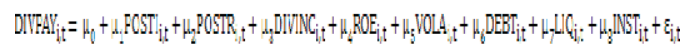

Where; DIVPAYi,t - Dividend pay-out ratio of company $i$ at time $t$; POSTIi,t Dummy variable for the post DDT introduction period, which takes the value 1 for period after introduction of DDT (2007-2014) for companies with positive profits, or 0 otherwise; POSTRi,t - Dummy variable for the post DDT threshold relaxation period, which takes the value 1 for period after relaxation of DDT (2011-2014) for companies with positive profits, or 0 otherwise; DIVINCi,t- Dividend income as a proportion of profit after tax of company $i$ at time $t$; ROEi, - - Return on Equity of company $i$ at time $t$; VOLAi,t- Volatility of company i's profits measured by the standard deviation of profits over three years $(\mathrm{t}-2$ to $t)$; DEBTi,t - Debt to Equity ratio of company $\mathrm{i}$ at time t; LIQi,t - Cash balance of company $i$ as at the end of year $t$ as a proportion of profit after tax; INSTi,t-Percentage of institutional and corporate investors of company $i$ at time
In the model, POSTI variable captures the impact of introduction of DDT on dividend payout, and POSTR variable captures the impact of relaxation of DDT threshold in 2011 on dividend payout. DIVINC measures the effect of dividend income of a company on dividend payout. All the other variables are incorporated as control variables.

2) Model 2: In addition to the main model, another model is used in order to measure the factors and their effect on dividend policy during the period before the introduction of DDT in 2007 (i.e. 2003-2006 period). This model functions as a supplementary instrument to compare results of the main model, as to find out the impact of DDT on the dividend payout and on the factors affecting dividend policy. POSTI and POSTR dummy variables are not included in the model, as POSTI and POSTR are time dummy variables for period after 2007 and 2011 respectively. All the other variables are same as the main model and capture the effect of factors affecting dividend policy before introduction of DDT. Evaluating the determinants of dividend policy of Sri Lankan companies before the introduction of DDT helps to compare and find the impact of DDT on dividend policy of Sri Lankan companies. 


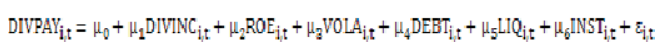

\subsection{Regression analysis}

Both the above models are analyse using the Tobit regression model following Al-Kuwari (2009) and Desalandes et al. (2015). Tobit regression assumes that dependent variable has certain limitations, that it cannot take certain values (Tobin, 1958). Thus, Tobit regression is the most appropriate method to nalyse the dividend payout policy of companies, because in the case of the dividend payout, it is limited only to positive values. Tobit regressions are run by censoring left side at value 0 , because dividend payout ratio cannot be a negative value.

\section{Analysis and Discussions}

\subsection{Descriptive statistics}

Table 2 below show that during the study period 817 companies $(68.1 \%$ of total observations) of the sample have distributed dividends. It further shows that number of companies who distribute dividends have increased after the introduction of DDT in 2007; as, 284 during POSTI period and 287 during POSTR period compared to 246 during PRE-period. The percentage of companies who distributed dividends from total observations for PRE, POST and POSTR periods are $61.5 \%, 71 \%$ and
$71.8 \%$ respectively. This hints that introduction of DDT in 2007 possibly has induced companies who did not distribute dividends earlier, to distribute dividends. Similarly, Chetty and Saez (2005) also find that a large number of companies have initiated dividend payments after the 2003 US tax reform which included a large dividend tax rate cut. Additionally, the mean dividend payout ratio of companies which distributed dividends, have increased during the study period. Mean dividend payout ratio has increased gradually from $36.5 \%$ during PRE-period to $37.3 \%$ during POSTI period and further to $45.3 \%$ during POSTR period.

Table 2. Summary of sample data

\begin{tabular}{|c|c|c|c|c|}
\hline & $\begin{array}{l}\text { Total } \\
\text { sample }\end{array}$ & $\begin{array}{c}\text { PRE } \\
\text { period }\end{array}$ & $\begin{array}{l}\text { POSTI } \\
\text { period }\end{array}$ & $\begin{array}{c}\text { POSTR } \\
\text { period }\end{array}$ \\
\hline & 2003- & 2003- & 2007- & $2011-$ \\
\hline & 2014 & 2006 & 2010 & 2014 \\
\hline $\begin{array}{l}\text { No of firm-years } \\
\text { obs. }\end{array}$ & 1200 & 400 & 400 & 400 \\
\hline $\begin{array}{l}\text { No of firm-years } \\
\text { paid dividends }\end{array}$ & 817 & 246 & 284 & 287 \\
\hline $\begin{array}{l}\% \text { of firm-years } \\
\text { paid dividends } \\
\text { from total obs. }\end{array}$ & $68.1 \%$ & $61.5 \%$ & $71.0 \%$ & $71.8 \%$ \\
\hline $\begin{array}{l}\text { No of firm-years } \\
\text { with positive } \\
\text { profits }\end{array}$ & 1001 & 327 & 331 & 343 \\
\hline $\begin{array}{l}\% \text { of firm-years } \\
\text { paid dividends } \\
\text { who had positive } \\
\text { profits }\end{array}$ & $81.6 \%$ & $75.2 \%$ & $85.8 \%$ & $83.7 \%$ \\
\hline
\end{tabular}




\begin{tabular}{lcccc}
\hline $\begin{array}{l}\text { No of firm-years } \\
\text { with positive }\end{array}$ & 469 & 140 & 143 & 186 \\
$\begin{array}{l}\text { dividend income } \\
\text { No of firm-years }\end{array}$ & & & & \\
paid dividends & & & & \\
who had positive & 356 & 99 & 119 & 138 \\
dividend income & & & & \\
$\begin{array}{l}\% \text { of firm-years } \\
\text { paid dividends }\end{array}$ & & & & \\
who had positive & $75.9 \%$ & $70.7 \%$ & $83.2 \%$ & $74.2 \%$ \\
dividend income & & & & \\
$\begin{array}{l}\text { Mean dividend } \\
\text { payout ratio of } \\
\text { firm-years paid }\end{array}$ & $39.9 \%$ & $36.5 \%$ & $37.3 \%$ & $45.3 \%$ \\
dividends & & & & \\
\hline
\end{tabular}

Further the percentage of companies distributed dividends as a proportion of companies who had positive profits for the period are $75.2 \%$ for PRE-period, $85.8 \%$ for POSTI period and $83.7 \%$ for POSTR period. Number of companies who had positive dividend income and distributed dividends have increased over the years as, 99 for PRE-period, 119 for POSTI period and 138 for POSTR period. However, the percentage of companies distributed dividends that had positive dividend income does not follow the same pattern. The percentage of companies distributed dividends that had positive dividend income has increased from $70.7 \%$ during PRE-period to $83.2 \%$ during POSTI period, but has reduced to $74.2 \%$ during POSTR period.
Table 3. Descriptive statistics of the variables

\begin{tabular}{llcccc}
\hline & & Total & PRE- & POSTI & POSTR \\
Variable & & Sample & Period & period & period \\
& & $2003-$ & $2003-$ & $2007-$ & $2011-$ \\
& & 2014 & 2006 & 2010 & 2014 \\
\hline \multirow{2}{*}{ DIVPAY } & Mean & 0.2713 & 0.2246 & 0.2647 & 0.3247 \\
& SD & 0.8876 & 0.3222 & 0.3384 & 1.4643 \\
\hline \multirow{2}{*}{ DIVINC } & Mean & 0.1225 & 0.0569 & 0.0581 & 0.2524 \\
& SD & 2.1913 & 0.3683 & 0.3123 & 3.7645 \\
\hline ROE & Mean & 0.0783 & 0.0136 & 0.0904 & 0.1308 \\
& SD & 1.2126 & 2.0384 & 0.3002 & 0.4083 \\
\hline \multirow{2}{*}{ VOLA } & Mean & 0.1978 & 0.3788 & 0.1178 & 0.0966 \\
& SD & 1.4140 & 2.4124 & 0.2500 & 0.2827 \\
\hline \multirow{2}{*}{ DEBT } & Mean & 1.4128 & 2.1667 & 1.3379 & 0.7339 \\
& SD & 7.9180 & 11.8457 & 2.6703 & 6.3175 \\
\hline \multirow{2}{*}{ LIQ } & Mean & 2.4510 & 1.4032 & 4.5671 & 1.3826 \\
& SD & 29.7331 & 3.4715 & 51.2804 & 2.8532 \\
\hline \multirow{2}{*}{ INST } & Mean & 0.7409 & 0.7138 & 0.7426 & 0.7663 \\
& SD & 0.2266 & 0.2240 & 0.2251 & 0.2282 \\
\hline
\end{tabular}

Table 3 show that mean of dividend payout ratio of companies during the study period is $27.13 \%$ with a standard deviation of $88.76 \%$ while Gunathilaka (2014) also finds that Sri Lankan companies rely largely on retained earnings and have retained more than $70 \%$ of the earnings during 2006 to 2010 period, which indicates a dividend payout of $30 \%$.

Table 3 further indicates that average dividend payout ratio of companies has increased in POSTI (26.48\%) and POSTR (32.48\%) periods compared to PRE-period (22.46\%). Desalandes et al. (2015) also find that mean dividend payments of Canadian companies have increased after the dividend tax cut. 
Mean of dividend income as a proportion of PAT has risen significantly to 0.25 during POSTR period from 0.05 in PRE and POSTI periods. Mean value of ROE has gradually increased during the study period (PRE: $1.37 \%$, POSTI: 9.05\% and POSTR: $13.09 \%$ ). On the contrary, mean value of SD of profits of companies over three years has decreased over the period, from $37.88 \%$ during PRE-period to $11.78 \%$ in POSTI period and further to $9.67 \%$ in POSTR period. Average debt to equity ratio of companies has also fallen throughout the study period (PRE: 2.17, POSTI: 1.34 and POSTR: 0.73). Mean values of cash balance as a proportion of PAT during PRE, POSTI and POSTR periods are $1.40,4.57$ and 1.38 respectively. Average institutional and corporate shareholders percentage have increased gradually from $71.39 \%$ in PRE period to $74.26 \%$ during POSTI period and further towards $76.63 \%$ during POSTR period.

\subsection{Regression analysis}

1) Regression model for the total study period (2003-2014): Table 4 presents the results of the Tobit regression model for the total study period (2003-2014). Coefficient of POSTI dummy variable is 0.1857 which suggests a significant positive relationship with the dependent variable-dividend payout ratio, at $1 \%$. This indicates that dividend payout ratio of companies have risen subsequent to the introduction of DDT in 2007. This supports the findings of Chetty and Saez (2005) and Desalandes et al. (2015), which suggest that companies have increased dividends payments after dividend tax cut in US and Canada respectively. This also supports the view that companies try to reduce their tax liability. As a result, the Government has been able to increase the dividend payout of companies through introducing DDT as expected.

On the other hand, POSTR dummy variable is negatively related with dividend payout ratio. However, the effect of POSTR variable is not significant as POSTI variable and significant only at $10 \%$. Even though, the companies have reduced the dividend payout ratio subsequently to the relaxation of DDT threshold in 2011, the impact is not as significant as the impact from introduction of DDT to increase payout. Hence supports Lintner's (1956) view that mangers are reluctant to reduce dividend payout.

Table 4. Regression results for total study period (2003-2014)

\begin{tabular}{lcccc}
\hline \multicolumn{5}{c}{ Dependent variable: Dividend Payout Ratio (DIVPAY) } \\
\hline \multicolumn{1}{c}{ Variable } & Coefficient & Std. Error & z-Statistic & Prob. \\
\hline POSTI & 0.1857 & 0.0321 & 5.7687 & $0.0000^{* \star \star}$ \\
POSTR & -0.0615 & 0.0334 & -1.8422 & $0.0654^{*}$ \\
DIVINC & 0.3774 & 0.0055 & 67.8169 & $0.0000^{* \star *}$ \\
ROE & 0.5142 & 0.0527 & 9.7458 & $0.0000^{* \star *}$
\end{tabular}




\begin{tabular}{lrrrl} 
VOLA & -0.8114 & 0.0890 & -9.1097 & $0.0000^{* * *}$ \\
DEBT & -0.0048 & 0.0020 & -2.3384 & $0.0194 * *$ \\
LIQ & -0.0032 & 0.0027 & -1.1577 & 0.2470 \\
INST & 0.1339 & 0.0622 & 2.1526 & $0.0313 * *$ \\
C & -0.0393 & 0.0514 & -0.7658 & 0.4438 \\
\hline Mean dependent & 0.2713 & SD dependent & 0.8876 \\
variable & \multicolumn{2}{c}{ variable } & Akaike info criterion & 1.1922 \\
S.E. of regression & 0.3210 & Schwarz criterion & 1.2346 \\
Sum squared resid. & 122.6532 & Sch \\
Log likelihood & -705.3388 & Avg. log likelihood & -0.5877 \\
\hline Left censored obs. & 383 & Right censored obs. & 0 \\
Uncensored obs. & 817 & Total obs. & 1200 \\
\hline ***, **, * Significant at & $1 \%$, 5\% and 10\% levels, respectively. \\
\hline
\end{tabular}

Coefficient of DIVINC variable is positive and significant at 1\% level. Positive association between dividend payout ratio and dividend income predicts that the dividend payout is higher when a company has high portion of dividend income. Correspondingly, this suggests that companies try to distribute dividends using the dividend income they received, in order to transfer income tax exemption on dividends to the shareholders. Shareholders prefer tax exempt dividends as investors try to reduce their tax liability as found by Chaplinsky and Seyhun (1990). Thus, the positive association between dividend income and dividend payout ratio supports catering hypothesis of dividends as companies try to cater shareholders preferences.

Additionally, ROE positively affects dividend payout ratio of companies significant at $1 \%$. This suggests that companies pay higher dividends when the profitability level is high, and pay lower dividends when profitability of companies is diminished as discovered by Lintner (1956). This is in line with the findings of Abayadheera and Senaratne (2001), who find profitability as a significant factor affecting dividend policy of companies in Sri Lanka. Abdelsalam et al. (2008) also find that companies with higher return on equity distribute higher level of dividends. However, this finding refutes the findings of Gunathilaka (2014), which proposes a negative relationship between profitability and dividend payout in Sri Lanka. Gunathilaka (2014) suggests that companies with high earnings distribute lower dividends, whereas companies with low earnings distribute higher dividends in Sri Lanka.

Further Table 4 shows that coefficient of VOLA variable is -0.8114 and significant at $1 \%$. This means that companies pay higher dividends when they have stable profits and dividend payment is low when profits are highly volatile. This finding supports the findings of Desalandes et al. (2015), which indicatethatvolatility is negatively affecting dividend payout of companies. Dividend payout ratio's positive association with $\mathrm{ROE}$ and negative association with VOLA variables support signalling hypothesis of dividends. Companies use dividends as a tool to signal the profitability, 
stability of profits and future prospects of the companies. Thus, when companies have high and stable profits, they distribute higher dividends. This supports the findings of Pathirawasam (2009), who also find a considerable amount of information content of dividends in Sri Lanka supporting signalling hypothesis of dividends. Debt to equity ratio negatively affects dividend payout ratio significantly at $5 \%$ level. Higher leverage weakens the dividend distribution capacity of companies, hence decreases the dividend payout. The finding supports the findings of DeAngelo et al. (2006); but contradicts with the finding of Gunathilaka (2014) that suggests leverage has no influence over payout policy of Sri Lankan companies.

Coefficient of INST variable is positive and significant at $5 \%$. This suggests that high institutional and corporate shareholder ownership leads to high payout ratio. Institutional and corporate shareholders prefer dividends due to differential tax treatment favouring them as found by Han, Lee and Suk (1999) supporting tax clientele hypothesis. Gunathilaka (2014) also finds that institutional ownership of companies has significant positive relation with dividend pay-out in Sri Lanka. Additionally, Al-Najjar (2009) discovers that institutional ownership positively affects dividend pay-out of companies in Jordan. Alternatively, the positive association of dividend payout and institutional and corporate ownership suggests that institutional and corporate investors prefer to invest in high dividend paying companies supporting the findings of Allen, Bernado and Welch (2000).

Conversely, LIQ variable is negatively related to dividend pay-out but statistically insignificant which means cash balance of companies is not a significant factor that affects dividend policy in Sri Lanka. This result is conflicting with the findings of DeAngelo et al. (2006), who suggest liquidity position of companies significantly affects dividend policy of companies. However, supporting the current findings, Komrattanapanya and Suntrauk (2013) find that liquidity is insignificantly related to dividend policy of companies listed in Thailand Stock Exchange.

\section{2) Regression model for the PRE period} 2003-2006: Table 5 shows the results of the Tobit regression model for measuring the determinants of dividend policy of companies for the period before introduction of DDT (2003 to 2006). This shows the factors that affected the dividend policy of Sri Lankan companies before the introduction of DDT in 2007. 
Table 5. Regression results for the period 2003-2006

\begin{tabular}{|c|c|c|c|c|c|}
\hline \multicolumn{6}{|c|}{ Dependent variable: Dividend Pay-out Ratio (DIVPAY) } \\
\hline Variable & Coefficient & \multicolumn{2}{|c|}{ Std. Error } & z-Statistic & Prob. \\
\hline DIVINC & -0.0648 & \multicolumn{2}{|c|}{0.0838} & -0.7735 & 0.4392 \\
\hline ROE & 0.8113 & \multicolumn{2}{|c|}{0.1268} & 6.3992 & $0.0000 * * *$ \\
\hline VOLA & -0.5547 & \multicolumn{2}{|c|}{0.1121} & -4.9487 & $0.0000 * * *$ \\
\hline DEBT & -0.0173 & \multicolumn{2}{|c|}{0.0039} & -4.4801 & $0.0000 * * *$ \\
\hline LIQ & 0.0097 & \multicolumn{2}{|c|}{0.0068} & 1.4173 & 0.1564 \\
\hline INST & 0.2577 & \multicolumn{2}{|c|}{0.1152} & 2.2374 & $0.0253 * *$ \\
\hline $\mathrm{C}$ & -0.1017 & \multicolumn{2}{|c|}{0.0891} & -1.1418 & 0.2535 \\
\hline \multicolumn{2}{|c|}{$\begin{array}{l}\text { Mean dependent } \\
\text { variable }\end{array}$} & 0.2246 & \multicolumn{2}{|c|}{$\begin{array}{l}\text { SD dependent } \\
\text { variable }\end{array}$} & 0.3223 \\
\hline \multicolumn{2}{|c|}{ S.E. of regression } & 0.3037 & Aka & info criterion & 1.2272 \\
\hline \multicolumn{2}{|c|}{ Sum squared resid. } & 36.1674 & Sch & z criterion & 1.3070 \\
\hline \multicolumn{2}{|c|}{ Log likelihood } & -237.439 & Avg & g likelihood & -0.5936 \\
\hline \multicolumn{2}{|c|}{ Left censored obs. } & 154 & Righ & ensored obs. & 0 \\
\hline \multicolumn{2}{|c|}{ Uncensored obs. } & 246 & Tota & & 400 \\
\hline
\end{tabular}

Table 5 indicates that DIVINC variable is negatively related to dividend pay-out ratio but insignificant. This implies that dividend income has not affected companies' dividend pay-out significantly during 2003 to 2006 period. Coefficient of ROE is 0.8113 and significant, which means profitability has positively affected dividend pay-out during 2003-2006. Further, VOLA has negatively affected dividend pay-out significantly. Debt to equity ratio (DEBT) also has negatively affected dividend pay-out of companies during the period before introduction of DDT in 2007. Coefficient of LIQ variable is 0.0097 , which suggests a positive relationship with dividend payout ratio as suggested by previous researchers. However, the relationship is not significant. Institutional and corporate shareholders percentage (INST) also has affected dividend payout of companies and significant at $5 \%$.

3) Comparison between the two regressions: Several important indications can be derived by comparing the results of regression models presented in Table 4 and Table 5. Table 5 shows that dividend income was not a significant factor affecting dividend pay-out of companies during the period prior to the introduction of DDT (20032006). Further, it shows a negative association with dividend pay-out in that period. However, the regression results in Table 4 for total study period after incorporating the period after introduction of DDT with the period before introduction of DDT, shows that dividend income is a significant factor that positively affects dividend pay-out policy of companies. This provides evidence to that dividend income received by a company has become a significant factor that affects dividend pay-out of companies after the introduction of DDT in 2007.

Further, the positive association between liquidity position (LIQ) and dividend pay-out during period prior to introduction of DDT (Table 5) has changed to a negative association after incorporating the period after the 
introduction of DDT (Table 4). However, the association is not significant in both regression models. This suggests that companies consider reducing the tax impact rather than considering the cash balance of the companies when distributing dividends. Thus, the high cash out flow of dividend payment compared to paying only DDT (without distributing dividends) has not restricted companies to distribute dividends. Additionally, significance of leverage (DEBT) factor has reduced after the introduction of DDT. These changes in coefficient signs and significance demonstrate that introduction of DDT has affected the dividend pay-out policy of companies as a whole and also has altered factors affecting companies' dividend pay-out. Coefficient signs and significance of all the other factors remain similar to their impact before the introduction of DDT.

\subsection{Limitations of the study}

This study carried with 12 years of time span as the period of study which was divided as 2003 to 2006 (PRE) and 2007 to 2010 (POSTI) with 20011 to 2014 (POSTR). Among all companies in the CSE after considering selecting criteria, out of remaining sample it was considered only randomly selected 100 companies. As a result, it was covered only 18 business sectors of CSE. Financial sector was excluded as its high leverage level and could not notice companies listed under power and energy sector within study period.

\section{Conclusions}

It is found that a large number of companies have initiated dividend distribution after the introduction of DDT in 2007. Further, it is found that companies' dividend pay-out ratio has increased due to the introduction of DDT. Thus, it can conclude that introduction of DDT in 2007 has affected dividend pay-out of companies significantly. However, the relaxation of DDT threshold in 2011 has prompted companies to lower the dividend payout compared to the period 2007-2010, but to a lesser extent as indicated by the coefficient value-0.06 of POSTR variable which is only significant at $10 \%$ level.

Additionally, it is found that dividend income of companies was not a significant factor that affected dividend policy before 2007 i.e. before introduction of DDT. However, dividend income has become a significant factor that affects dividend pay-out policy of companies in Sri Lanka after the introduction of DDT in 2007. In addition, the findings of the study suggest that profitability of companies and institutional and corporate ownership of companies 
positively affect dividend pay-out policy of companies, whereas leverage and volatility of earnings affect negatively. However, it is observed that companies try to reduce tax liability of companies by distributing dividends to avoid paying DDT, rather than considering liquidity position of the company. Therefore, it is found that liquidity is not a significant factor that affects dividend pay-out policy of companies in Sri Lanka.

The findings of the study support signalling theory of dividends as they reveal that the managers of companies have paid high dividends when they have large and stable profits to signal the future prospects of the companies. Further, the findings support catering theory of dividends as it is observed that managers have distributed dividends using dividend income received by the companies to cater the preferences of shareholders.

Furthermore, it can be settled seeing that high percentage of institutional and corporate investors have invested in high dividend paying companies, that tax clientele theory is also supported by the findings of the study since institutional and corporate investors prefer dividends to benefit from taxation. However, the findings of the study repudiate the tax effect hypothesis as paying dividends in order to avoid paying DDT does not result in decreasing the company value.

\section{References}

Abayadeera, N., \& Senaratne, S. (2001). An empirical study of the factors influencing dividend policies of Sri Lankan companies. Proceedings of the Annual Research sessions 2000/2001, (pp. 1-12) Faculty of Management Studies and Commerce, University of Sri Jayawardenapura.

Al-Najjar, B. (2009). Dividend behaviour and smoothing new evidence from Jordanian panel data. Studies in Economics and Finance, 26(3), 182-97.

Al-Kuwari, D. (2009). Determinants of the dividend policy of companies listed on emerging stock exchanges: The case of the Gulf Cooperation Council (GCC) countries. Global Economy \& Finance Journal, 2, 38-63.

Allen, F., Bernardo, A., \& Welch, I. (2000). A theory of dividends based on tax clienteles. Journal of Finance, 55, 2499-2536.

Al-Malkawi, H., Rafferty, M., \& Pillai, R. (2010). Dividend policy: A review of theories and empirical evidence. International Bulletin of Business Administration, 9, 171-200.

Black, F. (1976). The dividend puzzle. Journal of Portfolio Management, 2, 58.

Chaplinsky, S., \& Seyhun, H. (1990). Dividends and taxes: evidence on taxreduction strategies. Journal of Business, 63, 239-60. 
Chetty, R., \& Saez, E. (2005). Dividend taxes and corporate behavior: Evidence from the 2003 dividend tax cut. The Quarterly Journal of Economics, 120 (3), 791-833.

DeAngelo, H., DeAngeloL., \& Stulz, R. (2006). Dividend policy and the earned/ contributed capital mix: A test of the life cycle theory. Journal of Financial Economics, 81, 227-254.

Inland Revenue Department of Sri Lanka, (2007). Inland Revenue (Amendment) Act, No.10 of 2007. Retrieved f r o m h t t p : / / w w w . i r d. gov.lk/en/publications/Income\%20Tax _Documents/IRActNo.10[E]2007.pdf

Inland Revenue Department of Sri Lanka, (2014). Consolidated Text of the Inland Revenue Act, No.10 of 2006. Retrieved from http://www. ird. gov.lk/en/ publications/ Income $\% 20$ $\mathrm{T}$ a $\mathrm{x}-\mathrm{D}$ o c u m e $\mathrm{n} \mathrm{t} \mathrm{s} /$ IR_Act_No_10[E]_2006_(Consolidati on_2014).pdf

Deslandes, M., Landry, S., \& Fortin, A. (2015). The effects of a tax dividend cut on payout policies: Canadian evidence. International Journal of Managerial Finance, 11(1), 2-22.

Fama, E., \& French, K. (1992). The crosssection of expected stock returns. The Journal of Finance, 47, 427-465.

Gunathilaka, C. (2014). What drives the payout policy? Evidence from Sri Lanka: A dynamic panel data analysis. Wayamba Journal of Management, 3 (2), 1-16.
Han, K., Lee, S., \& Suk, D. (1999). Ownership structure and firm performance: international evidence. Multinational Business Review, 7 (1), 92-97.

Komrattanapanya, P., \& Suntrauk, P. (2013). Factors influencing dividend payoutin Thailand: A tobit regression analysis. International Journal of Accounting and Financial Reporting, 3 (2).

Lintner, J. (1956). Distribution of income of corporations among dividends, retained earnings and taxes. American Economic Review, 46 (2), 97-113.

Pathirawasam, C. (2009). The information content of stock dividend announcements: Evidence from Sri Lanka. Central European review for Economic Issues, 12, 103-114.

Tobin, J. (1958). Estimation of relation ships for limited dependent variables. Econometrica, 26(1), 24-36.

Van Horne, J., \& Wachowicz, J. (2014). Fundamentals of financial management ( 13 th ed.). Retrieved from https://yamanfc.files. word press.com/2015/01/fundamentals-offinancial-management.pdf. 